\title{
THE PERCEPTION ON THE USE SOCIAL MEDIA IN LEARNING ENGLISH
}

\author{
Rahmawati Dwi Handayani, Muh Syafei, Aisyah Ririn Perwikasih Utari \\ Universitas Muria Kudus
}

\begin{abstract}
The objective of the research is to know the perception offourth semester students of Universitas Muria Kudus on the use social media in learning English. The researcher used descriptive qualitative research and the data was collected by the used of questionnaire. The participants are 50 students of English Education Department of UniversitasMuria Kudus. The result showed social media have good perception for the fourth semester students of English Education Department of UniversitasMuria Kudus. Social media have provided rich resource to learn English. It indicats that social media has positive contribution for learning English they are listening, reading, writing and speaking skill.
\end{abstract}

Key words: social media, learning english

\section{INRODUCTION}

In the age of the internet, social media has become an important thing in social interaction. Nowadays students are familiar with social media. Social media is an internet based tool and platform that develop and share information. It can be a share of words, photos, video, others. Social media is also called a tool of information and communication technology used by people to communicate online. The students use social media not only for communication but also for social working and learning. Hudson $(2017 ; 59)$ states that social media refers to websites and applications of which design is to allow people to share content quickly, efficiently in real time.

Learning is a process to get knowledge of a subject or skill by study, experiences and instruction. Learning English is a process of getting knowledge about English skills (Brown 2010:7-8). English skills consist of four aspects. They are listening, speaking, reading and writing skill. The students of English Education department must master English well. Learning English is one of important thing for English majors. Most of the students of English Education Department learning English with technology resource as internet media.

Based on the researchers' observation while studying in English Education Department, the researcher finds that the students of English Education Department like using social media for different purposes. The students open social media for entertaining and also learn English.The students think that open social media has many kinds of resources such as video, photos, caption and others. For this reason, the students using social media for learning English makes the students easy to learn and has a lot of benefits. According to Al - Arif $(2019 ; 235)$ social media provides fun learning resources so that it makes students interest learn English language skills by using social media. The other reason the 
students use social media for learning English when students felt difficult and want to improve English skill. There are many kinds of social media for example Facebook, YouTube, Twitter and others. Monica and Anamaria (2014)

Social media has a positive impact on the students for learning English. Through social media the students can communicate with their friends and other people around the world. Students can increase and exchange information or knowledge and information. By read and watch some information. The students get a lot and information from social media. The third is social media make students creative. The cause is that social media has many resources for learning English. They are listening, speaking, reading and writing. The students can create their content creatively for example design photos.

Based on the explanation above, this study is to know the perception of fourth semester students of English Education Department of UniversitasMuria Kudus on the use of social media in learning English. By conducting this research, the result will be useful for the next researcher who wants to conduct similar research, the lecturer and the reader will use social media as a tool of learning English.

\section{METHOD}

This research uses qualitative descriptive research. Sukmadinata $(2010 ; 8)$ stated that qualitative research is to describe and analyse phenomena, events, social activities attitudes, beliefs, perceptions, though of individuals or groups. The participants of this research are 50 fourth semester students of English Education Department of UniversitasMuria Kudus. To collect the data researcher used a questionnaire. It is Close ended questionnaire. There are four categories of the questionnaire and they are Strongly Agree, Agree, Disagree and Strongly Disagree.

In analysing the data the researcher uses formula to calculating the percentage. Then, the researcher interpreting the result by scoring the result percentage of the questionnaire (Healey, 2011:2).

$$
\%=\frac{\mathrm{F}}{\mathrm{N}} \times 100
$$

\section{RESULTS AND DISCUSSION}

After analyzing 50 responses from the fourth semester students of English Education Department of UniversitasMuria Kudus, the perception and the score of social media used are presented in the following table:

Table 1 The Perception on the use Social Media in Learning English

\begin{tabular}{lcc}
\hline No & Perception & Score \\
\hline General Statement & & \\
\hline 1. Social media provide rich resources as quotes, caption, photos, videos & 178 \\
\hline
\end{tabular}




\begin{tabular}{|c|c|}
\hline and other types of resources to learn English & \\
\hline 2. Social Media make learning English easier & 173 \\
\hline 3. Social Media are important tools in learning English & 173 \\
\hline 4. Learning English using social media is fun & 173 \\
\hline $\begin{array}{l}\text { 5. Social media motivate me to communicate in English language with } \\
\text { each other }\end{array}$ & 169 \\
\hline 6. I will keep on using Social media to learn English in the future & 169 \\
\hline $\begin{array}{l}\text { 7. Learning English through Social Media helps me become an } \\
\text { independent learner }\end{array}$ & 159 \\
\hline 8. Social Media have boost students' confidence in learning English & 158 \\
\hline \multicolumn{2}{|l|}{ English skill } \\
\hline I can learn new words and improve my vocabulary from social media & 190 \\
\hline Social media make me easier to share my ideas & 175 \\
\hline Social media helps me to learn English & 172 \\
\hline $\begin{array}{l}\text { I improve reading skill by reading caption and others resources in } \\
\text { English }\end{array}$ & 172 \\
\hline I listen to a lot of video about English learning on Social Media & 171 \\
\hline $\begin{array}{l}\text { Social media give me a positive impact on listening, reading, writing } \\
\text { and speaking skill }\end{array}$ & 166 \\
\hline I improve my listening skill on English through social media & 166 \\
\hline I improve my reading skill on English through social media & 164 \\
\hline Listening English video helps me learn English pronunciation & 163 \\
\hline Through social media. I can practice writing skill & 159 \\
\hline I improve my speaking skill in English through social media & 159 \\
\hline I improve my writing skill on English through Social media & 150 \\
\hline I read an English article on social media & 150 \\
\hline Social media helps me to apply grammar rules & 150 \\
\hline $\begin{array}{l}\text { I often speak English with my friends through social media by video } \\
\text { call }\end{array}$ & 115 \\
\hline
\end{tabular}

Based on the result of the questionnaire of the perception of the fourth semester students of English Education Department of UniversitasMuria Kudus on the of use social media in learning English, it is found that social media provide rich resources as the quotes, caption photo and others type of resources to learn English with a score 178. It means that the students "Agree" that social media provides them to learn English. Students read caption, tweets and watching videos about learning English and others. It makes the students easily learn English with many sources.

The second statement is "Social media make English Learning easier" it shows with scores 173 . The students choose "Agree" it means that the students 
felt easy to learn English by using social media. The students get much knowledge easily by open their social media.

The third statement is "Social media is an important tool in learning English" it shows with 173 scores. The students "Agree" with these statement. The students think that it is important because the students can learn by other ways to improve their ability English skills.

The fourth statement is "Learning English with social media is fun" with the score 173. The students felt enjoy and happy when the students learn with social media. It is because social media provide many resources so the students didn't get bored. The next statement is "Social media motivate me to communicate with others" it is got sores 168 . The students can share their ideas by comments, sending the message. These can also reference the theory of Baruah $(2012 ; 36)$ stated that social media is social interaction as a tool of social communication.

The sixth statement identified" I will keep on social media to learn English in the future" with a 169.it is indicated the students always updated the information about learning English and others it is so good to use in the future. according to Sari (2010), "Social media can influence the students improve their English skills.

The seventh statement shows that "Learning English through social media helps me became an independent learner. With 159 scores. The students feel free to choose the time and what the students need for the content of learning English.

The last statement of the general statement is "social media is has boosted the students confident in learning English" the student's don't feel afraid when

The highest score for the statements is "I can learn the new words and improve my vocabulary in social media". The result shows that 190 . The 40 students Agree. It meant $=\mathrm{s}$ that the students can improve their vocabulary through social media. The students can read by post, caption, video, pictures and comments and others. There are so many words so the students can improve and remember the new words.

The second statement is "Social media makes me easier to share ideas using English language with others" it shows 175 scores. The students "Agree". It means by social media the students easily share their ideas by update statues, feeds, make videos or photos with a caption that make the student create and share their idea.

The third statement is "Social media help me to learn English. It shows 172 scores. The students feel helpful when learning using social media. There are so many resources to learn English by social media.

The fourth statement is "I can improve my reading skill by read caption" it shows 172 scores. The students Agree by reading caption can improve their ability especially reading skills.

The fifth statement "I listen to a lot of video about English learning on social media" it shows 171 scores. There are a lot of videos about learning English. For example YouTube. It is provides videos about education, entertainment and others about learning English. So the students watching YouTube improve their English skills. 
The sixth statement "Social media give me a positive impact on listening, reading, writing, speaking skill. It shows 166.

The seventh statement "I improve my listening skill through social media" the students improve their listening skill by watching video and listening audio. The students always do it so the students can improve their listening ability.

The eight statement is "I improve my reading skill in English through social media" it shows 164 scores the students "Agree" by reading some information, caption, tweets and others. The students always read it. So, students develop their English skills.

The next statement is "Listening English video helps me learn English pronunciation". It shows 163 scores. The students agree that after watching the video the students know the right spell or pronunciation by listening video/audio.

The tenth statement "Through social media, I can to practice my writing skill". It shows 159 scores. The students can develop their writing skills by writing the caption, commenting on posts and others. It makes them good in structure, grammar and others.

The eleventh statement" I improve my speaking skill in English through social media. The students try to practice their listening skills with their friends.

Then, the twelve statement is "I improve my witting skill on English through social media. It got 150 scores. The students able to write well through social media.

The thirteen statement is "I read English article on social media "It shows 150 scores. The student always read English article through social media, there are many articles, news, information on social media.

The fourteen statement are"social media help e to apply grammar rules" the students who agree that the student applies grammar rules there are some students felt difficult to apply the right grammar rules. It because the students do not know well how to arrange a good paragraph using right grammar.

The fifteen statement "I often speak English with my friends through social media by video call" it shows 115 scores, the students seldom practice video call with their friends through social media.

From the result of the research, the researcher concludes there were many students perception regarding 2 aspects. There are general statements and English skill this result was confirmed by the previous researcher. The first Selly, Irene (2018) who found in her research the students have positive perception in learning English. The students felt learning English using social media was so fun, flexible and helpful platform to learn English. The second is Mismara,Jannati (2018) the students have a positive impact after using social media as a tool for learning English. The third Al Arif (2019) learning using social media makes the students more attractive and easy to be practice.

\section{CONCLUSION}

The result shows that the students have positive perception of fourth semester students of English Education Department of Muria Kudus on the use of social media. It means the use of social media is supporting learning process 
implemented online, as the social media are popular so that everybody use, as well as the students.

Based on the conclusion above, some suggestion proposed as follows. First, the use of social media of the fourth semester students of UniversitasMuria Kudus should be use to help the lecturers manage their teaching and learning process. The lecturer can use social media as a learning tool to help students develop their English Language skills. Next, the students should try and use others social media for learning English. Next, the researcher recommended the next researcher to conduct similar research by exploring other aspects of using social media in learning English.

\section{REFERENCES}

Al Arif, T. Z. Z. (2019). The Use of Social Media for Learning Language Learning: An Exploratory Study of EFL University Students. Metathesis: Journal of English Language, Literature, and Teaching, 3 (2), 224-233.

Baruah, T. D. (2012). Effectiveness of Soial Media as a tool of communication and its potential for technology enabled connections: A micro-level study. International Journal of scientific and Research Publications, 2(5),1-10

Grabe, W,.\& Stroller, F. L. (2019). Teaching and Researchig. Routladge

Mismara, J. (2019). Student's Perception on Using Social Media for Learning English (Doctoral dissertation), UIN Sr-Raniry, Banda Aceh)

Monica-Ariana, S., \&Anamaria -Mirabela, P (2014). THE IMPACT OF SOCIAL MEDIA ON VOCABULARY LEARNING CASE STUDY- FACEBOOK. Annals of the University of Oradea Economic Science Series, 23(2)

Sari, R,F. (2018). The influence of social media sites toward studnets; English Language skills (Doctoral Diserartion, IAIN Palangka Raya)

Sakkir, G., Rahman, Q., \&Salija, K. (2016). Students' Perception on Social Media in Writing Class at STKIP MuhammadiyahRappang, Indonesia. International Journal of English Linguistics, 6(3), 10-175.

Sely, K. I . E. (2018). A study on students Pereption of Social Media to learn English as A foreign Language. (Doctoral Diseratation, UNIKA SOEGIJPRANATA SEMARANG)

Sukmadita, N. S. (2005). Metodepeneltianpendiidkan. Program PascasarjanaUniversitas Linguistics, 6 (3), 170-175. 